\title{
Study on optimizing the environment of college students' self employment
}

\author{
Chunyan Jiang ${ }^{1, \text { a }}$ \\ ${ }^{1}$ School of economy and management, Shijiazhuang Tiedao University, Shijiazhuang 050043, \\ China. \\ ajiangchunyan0525@163.com
}

Keywords: Self employment, College students entrepreneurial environment, Campus culture, Fiancial support.

\begin{abstract}
To encourage innovation and entrepreneurship is the fundamental way to cultivate talents and solve the problem of employment. Based on the data from market survey, This paper analyzes the main problems of the current environment of college students' self employment, such as lack of campus culture, financial support, construction of infrastructure and policy propaganda, then puts up the targeted suggestions.
\end{abstract}

\section{Introduction}

With the contradiction between the increasing sharply number of college students and the difficulty of employment, it is an important way to solve the problem of employment that encouraging college students to be self-employed. But the truth is that the activities of college students' entrepreneurship leaves much to be desired which raises concern about the problem of college students' entrepreneurial environment among the society. As for the study about entrepreneurial environment, the researchers from all over the world focus on two aspects including the definition and component factors of entrepreneurial environment. For the definition of entrepreneurial environment, Child looked it as the object of an enterprise's own perception; Aldrich considered it to be a series of external conditions to which an enterprise has to adapt; Desai, Gompers and Lerner come up with a concept that entrepreneurial environment is institutional environment essentially, including the system of standard, regulation and cognition; Chi Ren-yong, a domestic scholar, gave a definition that entrepreneurial environment is environment around entrepreneurs, the basis of generation, a complex social system consisting of entrepreneurial culture, policy, economy and technology, a multifaceted organic entirety; Zhang Yuli and Chen Lixin thought entrepreneurial environment is the element combination which makes a difference in entrepreneurial activities including all elements such as politics, economy and social culture influencing kinds of entrepreneurial activities and the possibility of getting help and support of entrepreneurship.

The two influential economic models - five-dimensional model and GEM model - are used mainly to study about the component factor of entrepreneurial environment. Five-dimensional model was built by Gnyawali and Fogel in 1994, in which the five dimensionalities of entrepreneurial environment are the skill of entrepreneurship and management, social economy condition, policy and working routine of government, financial support and non-financial support. GEM was built based on the project researching the entrepreneurial activities around the world by London Business School and Babson College, in which there are nine aspects about entrepreneurial environment. Besides, Shane put forward that entrepreneurial environment should include political environment, economic environment and social culture environment. Many domestic scholars also gained some researching achievements. For instance, Chi Renyong put forward that entrepreneurial environment should consist of six subsystems including entrepreneurial network system, entrepreneurial risk management system, entrepreneurial incubator system, entrepreneurial training system, enterprise training system and compensation for success system when he studied on the comparison between different entrepreneurial environment America and Japan. Zhang Liyu thought that entrepreneurial 
environment should include four aspects: social economy condition, policy and working routine of government, financial and non-financial support, skills of entrepreneurship and management.

This paper based on the market survey, using SPSS statistical software and GEM - builds an entrepreneurial environment model of Chinese college students, analyzes the influence and factors of entrepreneurial environment on college students’ entrepreneurship and gives some suggestions.

\section{The problems of entrepreneurial environment of college students}

\subsection{Campus culture environment lacks encouragement on entrepreneurial innovation.}

Campus culture environment mainly involves existing campus culture, social regulation's attitude to entrepreneurship, failure, risks and wealth creation. Positive entrepreneurial culture, which is critical to entrepreneurial intention of college students, promotes innovation and entrepreneurship and encourages people to get success through individual efforts. Entrepreneurial innovation of college students will be restrained if the most of people doubt the value of entrepreneurship among our society. According to our finding, from 562 valid questionnaires, more than $30 \%$ of the students have a correct cognition of entrepreneurship and think that self- employment could help them realize the value of life, expand their career and reflect their ability. There are only $1.4 \%$ of the students objecting to entrepreneurship and thinking the more important thing for college students is studying. For the 562 students interviewed, when asked whether they plan to be an entrepreneur, 176 of them gave a positive reply, 277 of them were considering about it, and 109 students had never thought about it.According to our survey, more than half students who were interviewed spend 500 to 1000 yuan a month, and only 3.96\% of the students spend more than 2000 yuan; about $78 \%$ of the students' expenditures account for $60 \%$ to 100 of the money they own, while $4.63 \%$ of the students spend more than they own, which indicates that most of college students' expenditure is appropriate. 95\% of the students get their living expenses mainly from their parents. But the source of the expense becomes more diversified because of the rise of grade.

\subsection{Financing access of entrepreneurship is blocked}

Financial support dimension is used for reflecting the degree of financial support that college students can get when they start a business. Financial support includes equity capital, seed funding, presentation and government grant. For college students who have entered society for a short time, their money is mainly from their parents and friends so that their capital of entrepreneurship is limited, which leads to the fact that undercapitalization becomes the main obstacle for entrepreneurship. Entrepreneurial innovation of college students also will be restrained if effective capital resource can't be offered from external. From the current situation, there are few programs can get financial support finally while the amount of applications of entrepreneurial programs of college students is rising continually. The quantity of financial support ranges from 2000 yuan RMB to 2000 yuan RMB, from which we can see that the coverage of financial support is narrow and the efforts of support are small. According to the questionnaire, less than $5 \%$ of the students get financial from school, so their financing ability is limited.

\subsection{The construction of infrastructure is retarded}

College students need favourable infrastructure environment. The availability and acquisition costs of communication facilities, postal service, the Internet, public facilities, traffic facilities, land and office space as well as the complexity of getting raw material and natural resources affects that whether college students could start their business successfully or not. Entrepreneurial aspiration of college students will be encouraged if physical infrastructure can be obtained expediently. From the current university campus, innovation service used for incubation of innovative entrepreneurial teams belongs to the student affairs office. There are two aspects of work should be done by entrepreneurial service base. First, offer site and facilities, recruit good entrepreneurial programs and bring the eligible ones into the base to incubate and give them better education and training. Second, hold recommendation meets for the programs and invite the relevant enterprises and investment organizations to know about students' programs so that the teams could get more financial support. The staff in the service institution are those who working in student affairs office concurrently, leading to the lack of staff and the problem that service content is restricted to policy advisory and 
offering site and facilities. The institution can't provide students with professional service about industry and commerce, taxation, management, information and exploiting of access. The construction of infrastructure is retarded

\subsection{The policy propaganda encouraging entrepreneurship is retarded}

The government policy dimension is mainly used for inspecting support from local government about supporting innovative enterprise. These policies involve fund plan for leading entrepreneurship, preferential tax relief policy, financial support policy, enterprise training and government procurement plan. Obviously, positive policy can cut down entrepreneurial cost and strengthen entrepreneurial innovation of college students. According to the research, there are 280 informants saying that entrepreneurial policy encouraging entrepreneurship had been introduced, involving microfinance for entrepreneurship, a 5000 yuan reward for success, financial support for competition winners of entrepreneurial design and entrepreneurship science parks to provide platform for students' entrepreneurship. When asked about the attitude of administrative department, $64 \%$ of the students said initiative and 23 of them said not initiative. Another 282 students thought there were not any entrepreneurial policies in their schools.

The entrepreneurs in some universities contend for profit with rear service administrative group because their service objects are students and the programs are low -level. But most of the universities haven't taken any measures to limit entrepreneurship.

\subsection{Entrepreneurship education is a mere formality.}

Many domestic researches indicate that entrepreneurship education is an important motivation factor for entrepreneurship of college students, which helps college students know more about entrepreneurial journey and master entrepreneurial skills to boost their confidence of entrepreneurship, and increase their entrepreneurial passion by some successful cases. Entrepreneurship education aims at developing students' awareness, though and skills of entrepreneurship to make them possess entrepreneurial ability. But there are some problems when the universities set entrepreneurial education courses. First, entrepreneurship education which pertains to liberal education could apply to all kinds of subjects, it should be the education for all students and be integrated into the overall process of training professionals. But in the universities in the province, entrepreneurship education courses are set as optional with short class-hour (32 or 48) and limited credits for a part of students. Second, teaching form is based on traditional infusion in class so that students don't have opportunities of social practice and mentors from enterprises and society. Third, it is different for the teachers majored in economy and management to help students with specific links of entrepreneurship. These problems lead to serious polarization between the students learning the course. Some students who really want to start their business haven't basic quality and knowledge about entrepreneurship, but their schools can't provide them with enough time to realize their goals because they have to get enough credits. The students are in a dilemma because most of the schools haven't established the system of compensating professional credits for entrepreneurial credits. The have to concentrate on their studies when they cannot eat their cake and have it. The others who choose the course only for credits have no incentive in class.

\section{Conclusion and suggestions}

\subsection{Construct entrepreneurial culture environment}

A good atmosphere and culture of entrepreneurship can't be separated from nice construction of entrepreneurial culture environment. Rich atmosphere of entrepreneurship has positive influence invisibly for all students no matter whether they are preparing for atmosphere and culture of entrepreneurship or not. Developing students' entrepreneurial awareness always occupies the primary position in many external measures promoting atmosphere and culture of entrepreneurship of college students. For example, the YEP in DIM leads students to found micro-companies and the government invests businessmen to give lectures in universities termly.

Practices have proven that good culture atmosphere has great impact on the development of entrepreneurial talent. Spirit and actions of entrepreneurship will be encouraged in an air of strong entrepreneurial culture. Make use of campus broadcasting, scrolls and school board to strengthen 
publicity. Entrepreneurial clubs organize activities motivating students to start their business. University career center should analyze entrepreneurial practice activities to offer chances for students.

\subsection{Set up venture capital funds, remove the bottleneck of fund.}

According to the result of research, most of the universities haven't established any entrepreneurial service institutions or entrepreneurial science parks to offer professional service for students. So incubator bases could be established to offer convenience for students about venture capital, technical support and professional service. As the cradle of enterprise growth, a incubator base should improve its ability in every respect. For instance, synthesize all resources and advantages of school, expand the aspect of services, receive high-quality talents, develop professional service department and raise efficiency of incubation.

3.3 Broaden publicity channel, strengthen publicity and implement of entrepreneurial policy

In general, college students in Hebei province don't know about government's preferential policy of entrepreneurship because of insufficient propaganda. New preferential policy should be publicized widely with the help of medium like Yanzhao Metro Daily, school website, broadcasting station and entrepreneurial clubs so that the students aspiring to start their business are able to know about it by many ways.

\subsection{Strengthen entrepreneurship education, enrich the form and content of entrepreneurship education}

One of the connotations of the new normal of Chinese economy is making the transformation of economic development from factor-driven and investment-driven to innovation-driven. College students should be the main body of the future innovation. As supplier of educational resources, universities also should renew ideas, reform curriculum system, transform entrepreneurship education from optional to compulsory, broaden students' innovation and cultivate real entrepreneurial talents for society.

\section{Acknowledgement}

The paper is the part research of " Study on optimizing the campus environment of college students' self employment (No: 144576103D)", which accepted the fund of 2014 Hebei province science and technology plan projects.

\section{References}

[1]. CHILD J. Organizational structure, environmental and performance: the role of strategic choice.Sociology,. Vol.3 (1972):1-22.

[2]. ALDRICH. Organization and Environment. Fort Worth: Harcourt College Publishers. 1979:2-14

[3]. DESAI M, GOMPERS P, LERNER J. Institutions, capital constraints and entrepreneurial firm dynamics: evidence from Europe. NBER Working Paper No. 10165,Issued in December 2003.

[4]. Renyong Chi. Comparing the entrepreneurial environment between the United States and Japan. Foreign economies and management. Vol 24.(2002):13-19.

[5]. SHANE S A. General Theory of Entrepreneurship: Individual Opportunity Nexus. Cheltenham: Edward Elgar Publishing, 2003.

[6]. CLARK B R. Creating Entrepreneurial Universities: Organizational Pathways of Transformation. Oxford: International Association of Universities and Elsevier Ltd. 1998:5-18 